\title{
AN OVERVIEW OF THE EFFORTS MADE BY THE MUJADDIDEENS TO RENEW ISLAM
}

\author{
Dr Muhammad Sajjad \\ Lecturer: The Best College Bahawalpur
}

\author{
Muhammad Usman Khalid \\ $\mathrm{Ph}$. D Scholar, \\ Department of Islamic Studies, \\ University of Engineering \& Technology, \\ Lahore, Punjab, Pakistan,
}

\author{
Dr Iftikhar Aalam \\ Assistant Professor, \\ Islamic studies Dept. University of Okara, \\ Okara, Punjab, \\ Pakistan, \\ https://orcid.org/0000-0003-2832-0324
}

Article DOI: $\underline{\text { https://doi.org/10.36713/epra6205 }}$

\subsection{ABSTRACT}

In this research paper, an overview of Islamic revival, its basis from Quran and Sunnah, its history are elaborated in detail. A worldwide influx of Islamic revivalism rose beginning from 1970s owing in enormous part to famous disillusionment with the common country states and Westernized administering elites, which had overwhelmed the Muslim world during the former decades, and which were progressively observed as tyrant, ineffectual and lacking social authenticity. It was additionally a response against Western impacts, for example, independence, commercialization, co modification of females, and sexual freedom, which were viewed as subverting Islamic qualities and identities. Economic and segment factors, for example, slacking financial advancement, an ascent in pay imbalance and a decrease in social versatility, the ascent of an informed youth with desire for higher upward portability, and urbanization in the Muslim world likewise played a significant part.

KEY WORDS: Mujaddidian, Deen, Islam, Faith, revival, renewal, philosophy

\subsection{INTRODUCTION}

As far as the Renaissance Issues are concerned, the fact is that no periods has been left vacant by them, and in every age and country there have been born of devout people who have performed the reform and renewal tasks according to their current requirements. But there must be a fundamental point about all such efforts before the twentieth century, and that their real nature was not 'revival of religion' but protection of religion. Because the land of Islam had not yet been completely lost in the land, and no matter how much the true spirit of religion had fallen into disrepair, the structure of the civil and cultural system that Islam had established in the world was intact that the Shari'ah of Islam was in force in all Muslim countries. Therefore, the main goal of all Renewal Issues is to ensure that the practices of the religion are protected and maintained in their original form and that external influence does not distort the religion.

In Islam, the term renewed (Mujaddidian) came because of the hadith that the Prophet said, "Allah will send a person to this nation every century to renew 
the religion of Allah for this Ummah." Renewal means the return of religion to the state in which it was in the Prophecy. In this period, Islam was perfect and pure and exclusive in all respects, and then some defects and innovations began to be entered into it. Also one of the means of renewal is stated that renewal is simply the name of the revival of knowledge, namely the opening up of new layers of knowledge and manifestation. Therefore, in some Riwayat of Ahmad ibn Hanbal, the word "education" is found in the above Hadith. ${ }^{1}$

Allah Almighty said about duties and mission of The Holy Prophet (peace and blessings of Allah be upon him):

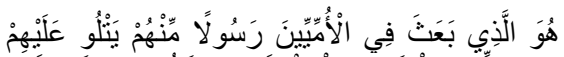

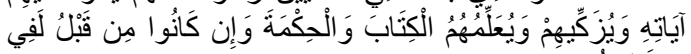

$$
\begin{aligned}
& \text { ضَنَالِ مُنِِينِ } 2
\end{aligned}
$$

It is $\mathrm{He}$ who has sent among them a Messenger, who recites His verses to them, and purifies them and reveals them and teaches them wisdom; surely they were in open error (astray) before (them).

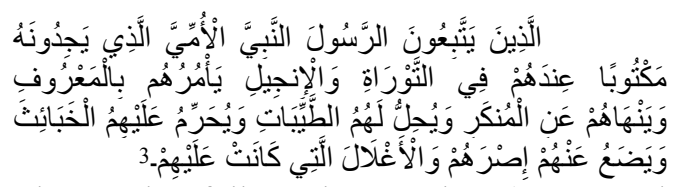

Those who follow the Prophet (peace and blessings of Allah be upon him) are the Prophets of the Ummi (ie the people of the Unseen and the Unseen) without reading to anyone in the world. They find those whom they have written in the Torah and the Gospel, who order them with good things and forbid evil things and make lawful things for them. They forbid things that are fair to them, and they deprive them of their barons, and their maidservants, which they have inflicted (on account of their disobedience).

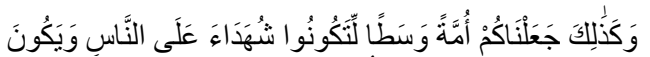

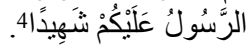

And thus have We made you a better nation, so that you may bear witness against the people, and (the Messenger of Allah) be a witness over you.

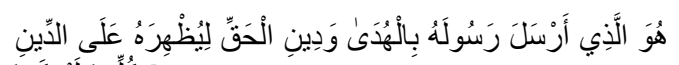

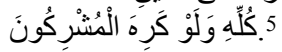

${ }^{1}$ Maudoodi, Syed Abul-Aala, Tajdeed o

Ahyaii Deen, Islamic Publications Lahore, 2016 p.31

${ }^{2}$ Surah Al-jumma: 2

${ }^{3}$ Surah Al-Aeraf: 157

${ }^{4}$ Surah Al-Baqarah: 143

${ }^{5}$ Surah Al-Taoubah :33
It is $\mathrm{He}$ (Allah) who sent His Messenger (peace and blessings of Allah be upon him) with guidance and the religion of truth so that he (the Messenger of Allah) would prevail over every religion (even), though the polytheists may feel bad.

The Mujadideen continued to pay these prophetic gifts to the Prophet (peace and blessings of Allah be upon him).

1. Recitation verses

2. Purification Self

3. Education book and wisdom

5. Nahi al-Munkar

6. Forbidding the lawful and unclean things of the pure, such as eating and eating halal and avoiding eating and earning forbidden.

7. Eliminating the burden of human life

8. Freeing the chains of slavery (national, regional, intellectual, social)

9. Establish the right of domination

10. To monitor global affairs and humanity

The Crowned Prophet (peace and blessings of Allah be upon him) alone brought all these things to the point of perfection in his outward appearance and the Khilafah Rashid was also a successor. The Rashidah era of the Caliphate will continue to be a role model for the entire universe and will continue to be renewed for it.

Allah promise the protection of the Holy Quran until the Day of Judgment for the Prophet Muhammad (PBUH)

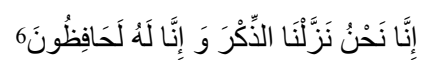

Indeed, this is the great (Qur'an) We have sent down, and surely we will protect it.

- Divine system of protection up to the Day of Resurrection of the Prophet Muhammad

- Duties of the Prophet (peace and blessings of Allah be upon him) by the Ummah Muslim (through a particular party).

- The role and identity of a particular party

$$
\begin{aligned}
& \text { - }
\end{aligned}
$$

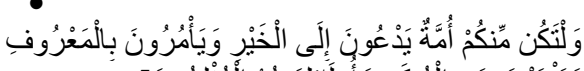

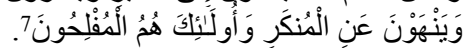

And there must be a group of you who call people to goodness and order good and prevent evil, and those are the ones who are evil.

\footnotetext{
${ }^{6}$ Surah Al-Hajr: 9

${ }^{7}$ Surah Al-Imran: 104
} 


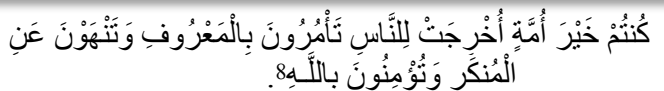

You are the best of the people who are shown to the people, you command the good and you forbid the evil.

Ummah Muslim Monitoring on Global Issues

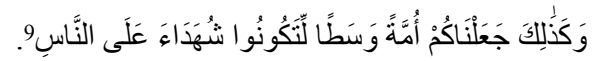

And thus have We made you a better nation, so that you may bear witness against the people.

Specific groups and groups refer to the religion, the mujahidin, and the mujahidin

If there is a slight deterioration in people's faith, beliefs, affairs and system, then the advisers will continue to correct it and if the deterioration is too high, people start to turn away from religion, then it becomes difficult to practice religion. Mujtahid will come for reform but if the values of religion start to decline. As the values of religion begin to change, the deeds of religion begin to change into a dead ritual. The slogans of religion started to be mocked, it seemed impossible to practice religion. If the anti-religion forces become too powerful, the name and work of the religion should remain for show only, the conditions for the practitioners of the real religion become very unsafe and if they face major calamities, then the Mujaddid Is sent.

\section{Protecting Religion by Mujaddideens}

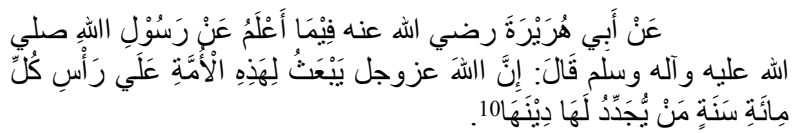

Hazrat Abu Hurairah (RA) narrates from what he learned from the Holy Prophet (peace and blessings of Allah be upon him) that the Prophet (peace and blessings of Allah be upon him) said: Allah Almighty for this Ummah at the end of every century He will create a person (or persons) who will renew his religion for this (Ummah).

\subsection{CHARACTERISTICS OF THE MUJADDIDEENS}

\subsubsection{God chooses the wise}

Such people are chosen from their childhood, their childhood is very different from ordinary children, they are very intelligent in their childhood, arrogant, talented, very hard working and creative. Parents are

\footnotetext{
${ }^{8}$ Surah Al-Imran: 104

${ }^{9}$ Surah Al-Baqarah: 143

${ }^{10}$ Imam Abu-Dawood, Sunan Abu-Dawood,
} Hadith no.3476/2 exposed to their work and location from childhood. God is Wonderful!

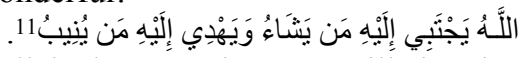

Allah chooses whom He wills in His presence, and guides to Him (every one) who turns (to Allah) in a heartly way.

\subsubsection{Direct beneficiaries of the Holy Prophet}

This Surah Friday verse also confirms the fact that after the Companions, the Tajiks are training the people of the universe and will continue to say it till the Day of Judgment. Even Imam Muhammad Mahdi (as) will be a great demonstration of the spiritual education and training of the Prophet (peace and blessings of Allah be upon him). In the world of the province, this series is known as Owaisiya. The spiritual, intellectual and intellectual training of the Saints in this regard is directly practiced by the merchants of the universe, such as Sayyidna Hazrat Sheikh Abdul Qadir Jilani (RA), Hazrat Shah Waliullah (RA), Hazrat Mujadd AlSani (RA) and others. There are many machinations and there will be especially religious religion.

Explaining the same concept, the Quran says:

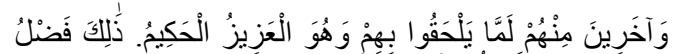

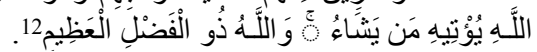

And among these other people (the Prophet (peace and blessings of Allah be upon him) sent for cleansing and teaching) who has not yet met those who are present (the Companions of Allah). Will come in time), and $\mathrm{He}$ is the Mighty, the Wise

\subsubsection{Knowledge renewal and Ijtihad and Ahia-ud-din}

Their knowledge is not conventional, but their knowledge is creative and refreshing, which brings solutions to difficult, unresolved and new problems.

The Qur'an calls them 'immortal persons' and orders them to approach them in case of difficult and unresolved problems.

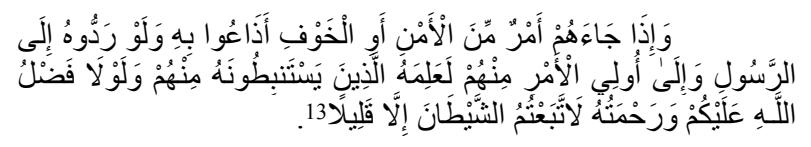

And when there comes to them any tidings of peace or fear, they spread it; and if they returned it to the Messenger (of Allah), and to their companions, they would surely return to it. Those of you who have come

\footnotetext{
${ }^{11}$ Surah Al-Shora: 13

${ }^{12}$ Surah Al-Jummah: 3,4

${ }^{13}$ Surah Al-Nisa: 83
} 
to know of this (truth) will know that, had it not been for the Grace and Mercy of Allah upon you, you would have followed the devil except a few.

Allah said: They will be knowledgeable for renewal and revival:

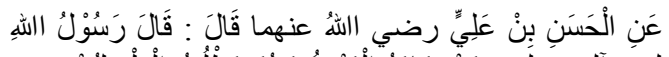

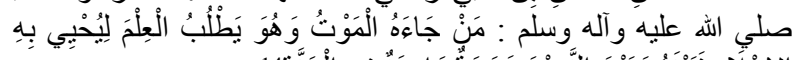

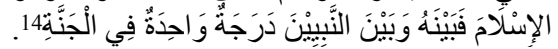

Hazrat Hassan ibn Ali (may Allah be pleased with him) said that the Holy Prophet (peace and blessings of Allaah be upon him) said: In the course of attaining knowledge, if a person dies and he is acquainted with it, he will bring Islam to life. There will be only one level of difference in Paradise between him and the Prophets.

\subsubsection{Knowledgeable Persons}

Their knowledge is not merely a book, but much of the knowledge is given by the directors of the Divine Prophet Muhammad (PBUH) as if a large part of their knowledge would be Wahhabi and not just books as Allah said:

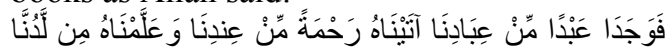

ع عِلْمًا

So both of them found one of our servants (Khadr) whom we had bestowed mercy on, and $\mathrm{We}$ gave him knowledge and knowledge of mystery and knowledge. ) Was taught

\subsubsection{Sahib Mazhar-ul-Ulema (may Allah be pleased with him)}

The Almighty has bestowed upon the universe the knowledge of the Divine Prophet.

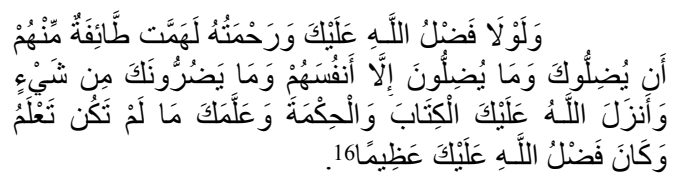

And had it not been for the Grace of Allah and His Mercy upon you, a party of them would have intended to seduce you, while they were misguiding themselves. And you can do nothing but spoil, and Allah has revealed to you the Book and the wisdom and He has given you all the knowledge you did not know, and Allah has great bounty on you.

$$
\begin{aligned}
& \text { قال رسول الله صلى الله عليه وسلم: "ما بال أقو ام }
\end{aligned}
$$

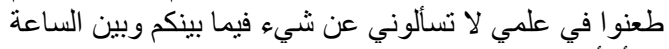

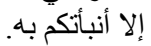

${ }^{14}$ Imam Tibrani, Al-Tibrani, hadith no. 5743/2

${ }^{15}$ Surah Al-Kahaf: 65

${ }^{16}$ Surah Al-Nisa: 113
The Prophet (peace and blessings of Allah be upon him) said: What will happen to the people who object to my knowledge? Ask me any question between you and the Hour, I will answer you.

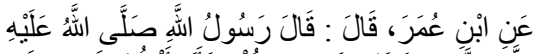

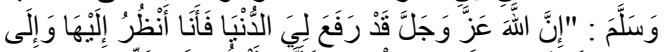

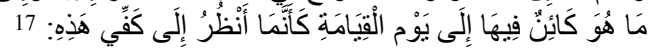

The Prophet (peace and blessings of Allah be upon him) said: Allah has raised the world and all that is in it until the Day of Judgment, and I see it as if I were holding my palm.

The scholars of the Universe do not hesitate to inform their slaves of this universe, but they give their share according to the capacity of each. God is Almighty!

$$
\text { وَمَا هُوَ عَلَى الْغَيْبِ بِضَنَينِ } 18 .
$$

And they (ie the Prophet) are not fully aware of the Unseen (the Lord of the Throne does not spare them).

\subsubsection{Sahib e Firast ( Having inner Perception)}

Allah Almighty gives them a special life in light and gives them a special light with this life. These men are with the light, they are on the light, the light is on, the light is from the Divine, and the light is distributed everywhere. These people do not live in the dark themselves, nor can anyone keep them in the dark, but anyone who sincerely associates with them does not allow them to remain in the dark. God is Almighty!

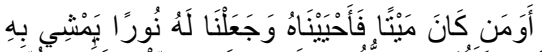

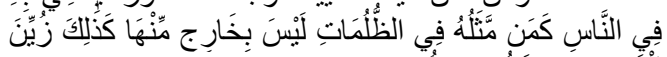

$$
\begin{aligned}
& \text { لِلْكَافِرِِينَ مَا كَانُو ا يَعْمَلَونَ } 19 .
\end{aligned}
$$

Is the man who was dead, then We revive him, and We have created for him light (of faith), through him (the rest)? I walk (to spread the light) like a person whose condition is (surrounded by ignorance and misguidance) in the darkness that it cannot escape.

\subsubsection{One-dimensional coordinates}

Some mujahidin renew only one area of life, such as beliefs, jurisprudence, mysticism, and politics

\footnotetext{
${ }^{17}$ Imam Abu-Nuaim, Hilyatul Aouliya, hadith
} no. $1569 / 3$

\footnotetext{
${ }^{18}$ Surah Al-Takveer: 24

${ }^{19}$ Surah Al-Anaam: 122
} 
in one of the fields of government, such as Hazrat Umar ibn 'Abd al-Uzzi in the government and caliphate, in Imam jurisprudence, and in Imam Sufism. In Sufism, in the last century, Hazrat Pir Meher Ali Shah was conscientious in the matter of Faith against Qadianism, and Allama Muhammad Iqbal (may Allaah have mercy on political awareness). All of these criminals were one-sided, but their specialization and specialization was in a single department.

\subsubsection{Two-dimensional coordinates}

Some of the Mujaddidis are those who renew the two fields of religion as Imam Ahmad Raza Khan (may Allaah have mercy on him) in the last century did a revisionist work on beliefs and jurisprudence. In particular, the way in which the Prophet (peace and blessings of Allaah be upon him) fought with disgust, was your own achievement, and so many of your judgments and decisions regarding jurisprudence were of a renewed nature.

\subsubsection{Three Dimensional coordinates}

There are some People who renew the religion. They reform all areas of faith, jurisprudence, mysticism and politics and government and re-presents the whole religion with a new spirit, making it viable and encompassing, like Hazrat Sheikh Syed Abdul Qadir Jilani. Hazrat Mujadid Al-Sani Sheikh Ahmed Sirhindi (RA). they are the great composer of the Islamic world whose renewed efforts were multifaceted and had far-reaching effects in every field of life. ${ }^{20}$

\subsubsection{The scope of the work of the Mujaddideens}

In the light of the Hadith of the Prophet (peace and blessings of Allah be upon him), Mujaddid primarily visits the end of the Islamic century and works so hard in his own field and department that religion becomes alive and bound for the next hundred years.

In the same area and age there may be separate assemblies for every religion and sometimes one can be given the responsibility of all the fields in a particular region, country, continent or global. The effects of the work of some Mujaddid religions have been around for a hundred years and there are fortunate ones whose work has been influenced for centuries such as Imam Jurisprudence, Imam Sufism and Spiritualism, Imame-Faith (RA). Shaykh Ahmad Sirhindi (RA). ${ }^{21}$

\subsection{Mujaddideens have two major targets}

The first: breaking the circle of narrow ideology, extremism and hatred around the minds of the people, enriching thoughts, moderating attitudes, and establishing an atmosphere of mutual respect and tolerance.

Secondly, the second major target of Mujaddid is to present religion in beautiful ways according to the needs of the contemporary.

In both aspects, the Mujaddid faced severe opposition from religious and semi-religious people. This opposition sometimes takes the direction of severe thunderstorms and storms, but due to the unwavering persistence and persistence of the Mujaddid, one day all opposition is dissipated. Sometimes this happens in the life of the Mujaddid, but often after the departure from the world, people gradually become convinced of the Mujaddid. ${ }^{22}$

We try to understand the necessity and significance of the role of Mujaddid in two examples:

1. If we draw three letters on a page that are initially parallel to each other, but after some distance the letters on either side are diverted one or two degrees out of the central letter, then over time the two letters become one. Others will move away and the distance and deviation from the central letter increases. These two letters are far apart from each other, but stay closer to the central letter than to each other, even as the distance or deviation from the central letter increases. Mujaddid always travels to the mainland

2. Consider another example! If a person stands in a narrow street and tries to see the whole city, he will see only a few houses. If you stand on the open road, you will see more houses, and if one looks at the height, then his eyes will be on more houses. As the height increases, more of the city will be visible, and a higher place will come where it will see the whole city, every little street and every corner, clear and bright. It is likely that Mujaddidi is likely to occupy the highest position. ${ }^{23}$

Until the time of Imam Hind Hazrat Shah Waliullah Dahlavi, the subjects of the Ummah were often confined to the field of knowledge, and the correctness of the doctrines of the faith remained their original target. And even if it steps forward, more and more refined morals, purification, and training of the spiritual. Going beyond this, the issue of religion did not take the form of a political or military movement

${ }^{22}$ Abdul-Kareem Zaidan, Islam min Riyasat aor Fard ka Mqaam, Islamic Book Publishers Lahore, p. 117

${ }^{23}$ Islam min Riyasat aor Fard ka Mqaam, p. 117
${ }^{20}$ Bunyadi Haqooq, p.133

${ }^{21}$ Bunyadi Haqooq, p.133 
until the last century. One of the main reasons for this was that the Prophet (peace and blessings of Allah be upon him) imposed very strict sanctions against the Muslim rulers, especially, the armed rebellion, and as long as the Shari'a-Islamic law was being practiced in their hands and any "infidel" The promotion of open and clear infidelity was not exaggerated, despite their self-inflicted woeful and oppressive armed rebellion against them. That is why as soon as this situation changed and the government came out of the hands of the Muslims and the non-Muslim nations were emerged, there was also militancy in the area who's most impressive and poignant example was the influence of the family of Shah waliullah, The movement of martyrs. This is why some people see the revisionist work of the former Muslim Mujaddidians as "partial" and they are surprised that no one has been born "perfect" in the fourteen hundred years of the Muslim Ummah. ${ }^{24}$

However, it is quite clear and straightforward that the building was not yet demolished, that a new construction was needed, but only partial reform was needed.

The first step in this revival process was the achievement of the Muslim nations to be saved from the direct domination of Western colonialism, which has been almost completed during the last forty years. And although we are still subjected to Western intellectualism and cultural hegemonic slavery and are under his control in many aspects due to the scientific superiority of the United Nations, thank God that there is one case, regardless of Palestine. Apart from Kashmir and Eritrea, no Muslim-majority area has been directly arrested in the curse of slavery and sectarianism throughout the entire region. ${ }^{25}$

From a purely theoretical and ideological point of view, the term "Muslim nations" is inaccurate. Because the Qur'anic recitation of Muslims is the status of Ummah, not a nation, and they are linked to an irreversible 'unity found' in which the frequency of occurrence is unlikely to be corrected by the word of the nations. But from a realistic point of view, the fact is that Muslims had long ago abandoned the role of Ummah or Hizb and took over as one nation. However, the concept of unity remained until the beginning of this century. But as we have already stated, during the first part of this century, the tactics of western colonialism were abolished, and at present there is no single 'Ummah' settled on the ground. ${ }^{26}$

\footnotetext{
${ }^{24}$ Tajdeed o Ahyaii Deen, p.33

${ }^{25}$ Hifzul-Rehman Siouharvi, Akhlaq aor

Falsfa Islam, Dehli 1950, p.334

${ }^{26}$ Islam min Riyasat aor Fard ka Mqaam, p. 117
}

Similarly, from a purely conceptual point of view, the freedom and sovereignty of Muslims by "not having the intoxication scale" has nothing to do with Islam. But from a realistic point of view, nothing can be said about the future, it may be that Allah will bestow the honor of obeying His religion to a completely new nation and the glory of Jesus Christ again appears. But if there is a revival, it is possible that the stench will not remain ".27

\subsection{Many Renewal in a century}

In addition to the differences in determining the names of the Mujaddids, some scholars have also suggested that there may not be many Mujaddis in one century. Seyouti attributed this opinion to Jamhour Ulema in his book Manojmu Manzoom. Seyouti has emphasized one thing that Mujaddid is from Ahle-Bait, and he is the only one in this century, although not all of the Mujadidis whose names are enumerated in their collection are from Ahle-Bait. And Imam Sabiki has enumerated the names of all the $2^{\text {nd }}$ century Renewals of the Maslake Shafi'is, but there is no one who agreed with his point of view.

The second opinion is that the Mujaddid may be one or more of the same at the same time. This opinion is from Ibn 'Asir Jazri, Shamsuddin Dhabi, Ibn Kathir and Ibn Hajar Esqalani. ${ }^{28}$

Jaziri says that in religious matters in general, the Ummah has benefited from other classes as well as the jurists, such as the Hadith to protect and enforce religion and to establish justice and law in the society. An important part of Sharia is that the Ummah has benefited greatly from the Hadiths and Ashab e Hadith, and from the Qur'an to preserve its traditions, as well as Abidin, Zahidin, Sufis and Sermons. Jazari has also added some Shi'ite imams to the list of Mujaddidin, but Shamsul Haq Azeem Abadi has disputed Ibn Athir's opinion. ${ }^{29}$

Muhammad Rashid Raza Misri in his book "Musoa-e-Aelam al-Mujadddin-Fi-IIslam" also enumerated those Renewals whose revival was limited not only to a region or a nation, but also to those who committed renewal in the war. As well as those who have renewed their knowledge in other fields of life also. ${ }^{30}$

${ }^{27}$ Tajdeed o Ahyaii Deen, p.35

${ }^{28}$ Faruqi ,Burhan Ahmad, . Mujaddid's Conception of Tawhid, Nur Muhammad: Karkhanah Tijarat-i Kutub, Karachi ,p. 88

${ }^{29}$ Mujaddid's Conception of Tawhid,p. 89

${ }^{30}$ Misri, Muhammad Rashid Raza, Musoa-e-

Aelam al-Mujadddin-Fi-IIslam, Idarah Tabaat alMuniriyyah, Cairo, p.137 


\subsection{Imam Ibn Taimiyyah as a Mujadid}

In the wake of having seen the ascent and improvement of religious and philosophical development in Islam and the commitments made by the scholars and thinkers before the sack of Baghdad, we have now gone to a point which might be known as the pre-renaissance period throughout the entire existence of Islam. By ibn Taimiyyah's time religious philosophy, theory, and law had gained exceptional ground and offered ascend to various ways of thinking. Be that as it may, sadly, political discords and doctrinal contrasts sapped the solidarity of the Muslims and made their nations simple prey to Mongol attacks in the seventh/thirteenth century. It was at this basic crossroads that Imam ibn Taimiyyah showed up as a mujtahid (one qualified to frame an autonomous sentiment in Muslim Law) and called upon the individuals to return to the first lessons of Islam as they are found in the Qur'an and the Sunnah of the Prophet. ${ }^{31}$

It is hard to state whether ibn Taimiyyah was affected by any of his antecedents in his extra-common energy for presenting social and strict changes in the Muslim people group and for his unsympathetic mentality towards the scholars, the rationalists, and the Sufis. A nearby assessment of his works proposes that he followed none yet the early devout Muslims (salaf al-salihun) in detailing his plan of change. This is the reason his development is regularly called the Salafi development. His adage was, "Return to the Qur'an and the Sunnah of the Prophet." He challenged a wide range of developments (bid'ah). He accepted that Islam was ruined by Sufism, polytheism, religious philosophy (Kalam), reasoning, and by a wide range of superstitious convictions. He planned for cleansing the Muslim society of works on bringing about undue praise to the tombs of prophets and holy people. During his stay in Syria from 692/1292 to 705/1305, ibn Taimiyyah, thusly, composed books and treatises against the Sufis, the Mutakallimun, and the Aristotelian scholars. ${ }^{32}$

\subsection{Sheikh Ahmad Sirhindi as a Mujadid}

Sheik Ahmad Sirhindi, otherwise called Mujaddid Alf Thani, was the child of Sheik 'Abd alAhad Makhdum, who was a dedicated Muslim constantly restless to get otherworldly edification from

\footnotetext{
${ }^{31}$ al-Baghdadi, 'Abd al-Qahir Al-Farq:, Kitab al-Farq bain al-Firaq, Cairo, 1328 A.H, p.154/3

${ }^{32}$ Mohammad al-Hamid al-Faqqi, Naqd alMantiq: Idem, Naqd al-Mantiq Cairo, 1370/1950, p. 421,2
}

holy people. Sheik 'Abd al-Ahad Makhdum met Sheik Allah Dad at Ruhtas and Sayyid 'Ali Qawam at Juanput. He took in a lot from both and afterward came back to Sirhind and lived there until his demise in 1007/1598. An incredible ace of the considerable number of parts of contemporary information, he showed the pervasive course books on reasoning and religion to his understudies broadly. He was likewise a recognized expert on statute. The Mujaddid was an extraordinary strict fan. The development that he began in religion is as yet preceded by his adherents in different pieces of the Muslim world. His legacy is basic for a cutting edge remaking of strict idea in Islam. He was a Sufi however he didn't consider Sufism the sole point of life. For him it was only an unfortunate obligation, the end being finished and unrestricted adherence and devotion to the Qur'an and the Sunnah. For a basically simply gauge of his lessons one must think about him concerning his occasions. His books are a significant record of his training and thought. $\mathrm{He}$ gave us a treatise on Sufistic flawlessness, however the best of him is found in three volumes of letters. The absolute number of Maktobat in every one of these volumes is 535 . With certain special cases, these are orchestrated in their sequential request. Five of his letters have been lost. They demonstrate certain that the all encompassing information he had, and make a charming and illuminating perusing. ${ }^{33}$

\subsection{Shah Wali Allah as a Mujadid}

Of the two chiefs of thought who showed up during the early long periods of wantonness, Muhammad canister Abd al-Wahhab of Arabia and Shah Wali Allah of Delhi, the last possesses a progressively conspicuous position. $\mathrm{He}$ was an illuminator who during the stormy time of Indian history demonstrated the dumbfounded Mus-lims the correct way, the way of harmony and greatness. He was equipped with profound knowledge, significant learning, and gallant nobleness. Not long after his passing his idea offered ascend to a powerful development under the authority of Shah Ismail Shahid and Sayyid Ahmad Barelvi for freeing the Muslims from the grasp of Western government. Shah Wali Allah's impact was very across the board and entering. He changed the philosophical, political, social, and monetary thoughts inside the structure of Islam. Like an accomplished specialist he investigated and analyzed the different parts of Islamic mystery and Fiqh and revised them in a request that made them profoundly advantageous to the Muslim society. As per

${ }^{33}$ Khan, Ahmad Hussain, Jawahir

Mujaddadiyyah, Newal Kishore, Lucknow, 1998, p.73 
Iqbal, he was the primary Muslim to feel the inclination for reconsidering the entire arrangement of Islam without in any capacity splitting endlessly from quite a while ago. ${ }^{34}$

Shah Wali Allah planned for introducing Islamic idea in as lucid and intelligent structure as any theologico-philosophical framework could be. His style has all the philosophical nuance and infiltration about it and his teachings have a legitimate cogency and consistency outperforming those of numerous Muslim scholars.

His philosophical undertaking comprised in clarifying and settling acceptably the obvious logical inconsistencies and polarities between the everlasting qualities and the evolving conditions, the solidarity of God and the variety inside the universe, and so on. Right now the forerunner of Iqbal; anybody digging profound into Iqbal's Reconstruction of Religious Thought in Islam will discover the soul of Shah Wali Allah swarming this work from start to finish.

In Islamic mystery Shah Wali Allah attempted to brush out all unfortunate remote impacts, for example, a dismal sort of neo-Platonism and Vedantism. $\mathrm{He}$ focused on that veritable otherworldliness, as recognized from pseudoenchantment, energizes a functioning lifestyle that guarantees progress and success right now salvation in the great beyond.

Remarking on Shah Wali Allah's job as a Sufi, Professor Gibb expresses: "During the seventeenth and eighteenth hundreds of years a progression of amazing researchers endeavored to rehash the bases of Islamic philosophy in a way which split away from the formalism of the universal manuals and laid new worry upon the mental and moral components in religion. Among the more extraordinary figures right now, has not yet gotten the consideration it merits, were the Syrian Abd al-Ghani of Nablus (1641-1731) and the Indians Ahmad Sarhindi (1563-1624) and Shah Wali Allah of Delhi (1702-1762)."35

Shah Wali Allah made an interpretation of the Holy Qur'an into Persian regardless of oppo-sition and, in this way, brought the Word of Allah inside the compass of the basic man. His distinguished child, Shah Rafi al-Din, following his model, deciphered the Quran in Urdu and, along these lines, dissipated the preference against interpretations of the Holy Book.

${ }^{34}$ Shah Wali Allah, al-insaf fi Bayan-i Sabab al-Ikhtilaf, Urdu translation by Sadr al-Din Islahi, Lahore, n.d., pp. 29-80.

${ }^{35}$ H. A. R. Gibb, Mohammedanism, The New American Library, New York, 1955, p. 125.
In Hadith he resuscitated enthusiasm for the investigation of Imam Malik's Muwatta, which got raised according to researchers just through his endeavors.

In Fiqh, Shah Wali Allah assaulted the ordinary ideas winning during his time. His primary undertaking comprised in liberating the idea of the heavenly Law from the abstract components that had interfered into it, along these lines reestablishing to it the virtue and minimization that it had at the hour of the Companions.

He likewise attempted to connect the inlets that yawned among the differ-ent schools of Fiqh. As per him, all the common frameworks of Fiqh drew their motivation from one single source so that there could be no central contrasts in them; contrasts there had been and there would be, however these were contrasts in understanding just, not in standards. The essentialness of Shah Wali Allah's outlook in Fiqh from the perspective of welding the Muslim people group into one ummah can't be over-emphasized. ${ }^{36}$

Shah Wali Allah, as Shaikh Ahmad Sirhindi, made it sufficiently evident that Islam isn't a religion in the typical feeling of the term however a total code of life which points at singular exemplary nature as well as gives a structure to all individual and social exercises.

It was the impact of the extreme change achieved by Shah Wali Allah in the viewpoint of the Muslim people group in the different backgrounds that a relentless development under the initiative of Shah Ismail Shahid and Sayyid Ahmad Barelvi was set forthcoming. This caused the Muslim people group to understand the condition in which they had been left through a disregard of their confidence, or through an off base way to deal with it. ${ }^{37}$

There jumped up an enthusiastic want in the brains of the Muslims to recover their position, not just to guarantee the legacy of their past culture yet in addition to resuscitate the imperativeness innate in it. Despite the fact that the development endured rout on account of the imperialistic forces, yet it couldn't be controlled for all time. The time that slipped by between the affliction of Shah Ismail and late forties of the present century, is significant for it was the time during which the plant supported by the life-blood of Shah Wali Allah kept developing till it bloomed into the introduction of Pakistan. 


\subsection{CONCLUSION}

In this regard, the fact that the main emphasis of the Ulema is on the protection of the practice of the religion, rather than meeting the requirements of the translation and revival of Islam in modern times. Although there are some important differences in reality, For example, since the door of Ijtehad closed and the period of imitation were imminent, and communalism was shaken, scholars of every sect have been focusing on protecting and securing this particular form of religious practice, Which is credible to their particular sector group, with which the roots of sectarianism are becoming stronger. Secondly, because he did not study the sciences of modern and contemporary thought as directly and indirectly as Imam Ghazali and Imam Ibn Taymiyah had done in their own time, they were therefore in essence the basic requirements of security and theology. 